\title{
Ligand Control in Nuclearity of Zn Complexes Supported by Formamidinates
}

\author{
Yi-Ju Tsai, ${ }^{a}$ Wenfeng Lo, ${ }^{b}$ Qinliang Zhao ${ }^{*, a}$ \\ ${ }^{a}$ Department of Chemistry, University of the Pacific 3601 Pacific Avenue, Stockton, CA \\ 95211, USA \\ ${ }^{b}$ Department of Chemistry, Yeshiva University, 2495 Amsterdam Avenue, New York, NY \\ 10033, USA
}

Keywords: Formamidinate; synthesis; zinc complexes; structural analysis; nuclearity

Abstract: Using $N, N^{\prime}$-diarylformamidinate (DArF) ligands containing different substituents of varying steric properties as the supporting ligands, four $\mathrm{Zn}$ complexes of atypical structural geometries were successfully synthesized and fully characterized. Detailed structural comparison indicated steric hindrance of the ligands was a crucial factor in governing the geometry and nuclearity of the $\mathrm{Zn}$ products. DArFs with low steric hindrance to the metal centers produced two trinuclear Zn clusters ( $\mathbf{1}$ and $\mathbf{2}$ ) where all ligands were in non-symmetric coordination modes in both solid state and solution phase. DArFs with relatively bulky substituents led to the formation of bimetallic complexes $\mathbf{3}$ and $\mathbf{4}$ in a pseudo-paddlewheel geometry where each two $\mathrm{Zn}$ cores were held together by two DArFs parallel to each other. This study, together with the monozinc complex $\left\{\mathrm{HC}(\mathrm{NDipp})_{2}\right\}_{2} \mathrm{Zn}$ (Dipp = 2,6-diisopropylphenyl) in the literature, indicated that an increase in steric demands of the ligands lead to a decrease in nuclearity of the $\mathrm{Zn}$-formamidinate complexes. All product complexes were relatively thermally

\footnotetext{
${ }^{*}$ Corresponding author. E-mail address: qzhao@pacific.edu
} 
robust but air and moisture sensitive. A tetranuclear cluster with an interstitial oxide was obtained when a small amount of oxygen content was present during the synthesis.

\section{Introduction}

Since the first report of amidine synthesis from $N$-phenylbenzimidyl chloride and aniline in $1858,{ }^{1}$ amidine ligands have been used extensively to form complexes with elements across the periodic table. ${ }^{2}$ More specifically, $N, N^{\prime}$-diarylformamidines (DArFHs) with one $\mathrm{H}$ atom on the central carbon and one aryl substituent on each nitrogen atom have attracted much attention from inorganic chemists due to their convenient synthesis and versatile tunability exhibited through ligand modification. ${ }^{3}$ DArFHs can be synthesized directly from the condensation of appropriate aniline derivative with triethylorthoformate as shown in Scheme $1 .{ }^{4}$ A large number of formamidine derivatives modified through modification of the substituents on the aryl rings (e.g. alkyl, alkoxy, halo and nitro groups) have been obtained and shown to support metal complexes. ${ }^{5}$ The introduction of electron donating/withdrawing substituents with bulky variants on the aryl groups directly adjusted the electronic and steric properties of the ligands, thus altering the properties and reactivities of the metal complexes. ${ }^{6}$

Neutral formamidines can be used as a coordinating ligand but mainly bind in one coordination mode $\left(\eta^{1}, \mathbf{I}\right.$ in Figure 1$)$ in which the imine $\mathrm{N}$ atom binds to a metal atom. ${ }^{7}$ Deprotonated formamidines, namely formamidinates, present a conjugated donor set across the N-C-N backbone $\left({ }^{\mathrm{N}}\right.$ ) featuring two nearly identical N-C bonds. As a result of the charge delocalization, two four-electron coordination modes to metals can 
occur. These include bidentate chelating $\left(\eta^{2}, \mathbf{I I}\right)^{8}$ and bimetallic bridging $\left(\mu-\eta^{1}: \eta^{1}\right.$, III $)$ modes. ${ }^{9}$ Great coordinative versatility of formamidinates has been demonstrated when the negative charge on the N-C-N backbone of a formamidinate could localize on a single $\mathrm{N}$ site, forming an amide ion that binds to a metal ion in a monodentate mode $\left(\eta^{1}, \mathbf{I V}\right) .{ }^{10}$ The $\mathrm{N}$ lone pair on the imine group could further coordinate to a new metal atom $(\mathbf{V})$ or to the original metal atom $\left(\eta^{2}, \mathbf{V I}\right) \cdot{ }^{11}$ The extra lone pair electrons on the amide group could further bind a second metal atom in a non-symmetric coordination mode (VII). ${ }^{12}$ Coordination mode VIII, first witnessed in an Os cluster, ${ }^{13}$ involves each of the three lone pair electrons on the N-C-N backbone bound to an individual metal atom. Variation in the C-N bond lengths on the N-C-N backbone obtained from X-ray structural analysis was critical in distinguishing the non-symmetric coordination modes.

DArFH ligands can incorporate a broad range of transition metals, lanthanide metals and main group metals. ${ }^{3,14}$ There, however, have not been many structurally characterized zinc complexes supported by formamidinates. The few examples that have been structurally characterized in the literature, include a homoleptic monozinc complex $\left\{\mathrm{HC}(\mathrm{NDipp})_{2}\right\}_{2} \mathrm{Zn}$ (Dipp = 2,6-diisopropylphenyl) ${ }^{15}$ an amide-bridged dizinc complex $\left[(\operatorname{IZn})_{2}\left(\mu-\mathrm{N}^{i} \mathrm{Pr}_{2}\right)\left\{\mu-N, N^{\prime}-(\mathrm{NDipp})_{2} \mathrm{CH}\right\}\right], \quad{ }^{16}$ a bisformamidinate tetrazinc oxide $\left[\left\{\mathrm{HC}(\mathrm{NDipp})_{2}\right\}_{2} \mathrm{Zn}_{2} \mathrm{Et}_{2}\right]_{2} \mathrm{O},{ }^{15}$ a trizinc cluster $\left[\left\{\mathrm{HC}(\mathrm{NDipp})_{2}\right\}_{2} \mathrm{Zn}_{3} \mathrm{Et}_{2}\right](\mathrm{OEt})_{2},{ }^{15}$ and two oxygenated tetranuclear zinc clusters $\left[\mathrm{HC}(\mathrm{NR})_{2}\right]_{6} \mathrm{Zn}{ }_{4} \mathrm{O}(\mathrm{R}=\mathrm{Ph}, p$-Tol $) .{ }^{17}$ In general, the bulkiness of the ligands increases the intramolecular ligand-ligand repulsion, thus complexes of different geometries were obtained. ${ }^{18}$ Geometries and nuclearities of formamidinate-supported $\mathrm{Zn}$ complexes, however, were still unpredictable. To understand the correlation between the steric demands of the DArF ligands and geometry 
of the $\mathrm{Zn}$ products, reactions of five $\mathrm{DArFH}$ derivatives with diethylzinc were investigated. The DArFHs employed in this study were abbreviated as $\mathrm{DPhFH}, \mathrm{D}(3,5$ $\mathrm{Xyl}) \mathrm{FH}, \mathrm{D}(2,6-\mathrm{Xyl}) \mathrm{FH}, \mathrm{D}\left(2-{ }^{i} \mathrm{PrPh}\right) \mathrm{FH}$ and $\mathrm{D}\left(2-{ }^{t} \mathrm{BuPh}\right) \mathrm{FH}$ (Figure 2). Large steric hindrances from the alkyl substituents on the ortho positions of the aryl rings were present in the last three ligands $\mathrm{D}(2,6-\mathrm{Xyl}) \mathrm{FH}, \mathrm{D}\left(2-{ }^{i} \mathrm{PrPh}\right) \mathrm{FH}$ and $\mathrm{D}\left(2-{ }^{t} \mathrm{BuPh}\right) \mathrm{FH}$.

\section{Results and Discussion}

\subsection{Synthesis}

Syntheses of all DArFH derivatives utilized were achieved by combining corresponding anilines and triethylorthoformate in a 2:1 mole ratio via a direct condensation reaction, following literature methods. ${ }^{4}$ Zinc complexes was obtained by mixing DArFH ligands with commercially available metal-alkyl diethylzinc at $-30^{\circ} \mathrm{C}$.

Diethylzinc provided the $\mathrm{Zn}$ metal atoms and also acted as the internal base to deprotonate the formamidines. In Eq. 1, four-equivalent $\mathrm{DPhFH}$ or $\mathrm{D}(3,5-\mathrm{Xyl}) \mathrm{FH}$ and three-equivalent $\mathrm{ZnEt}_{2}$ yielded trinuclear clusters $\mathbf{1}$ or 2, respectively. Following Eq. 2, reactions of two-equivalent $\mathrm{D}(2,6-\mathrm{Xyl}) \mathrm{FH}$ or $\mathrm{D}\left(2-{ }^{i} \mathrm{PrPh}\right) \mathrm{FH}$ of high steric hindrance and two-equivalent $\mathrm{ZnEt}_{2}$ in THF produced dinuclear complexes $\mathbf{3}$ and $\mathbf{4}$, correspondingly.

$4 \mathrm{LH}+3 \mathrm{ZnEt}_{2} \rightarrow(\mathrm{L})_{4} \mathrm{Zn}_{3} \mathrm{Et}_{2}(\mathrm{~L}=\mathrm{DPhF}$ in $\mathbf{1}$ or $\mathrm{D}(3,5-\mathrm{Xyl}) \mathrm{F}$ in 2$)+4 \mathrm{C}_{2} \mathrm{H}_{6}$

$2 \mathrm{LH}+2 \mathrm{ZnEt}_{2}+\mathrm{THF} \rightarrow(\mathrm{L})_{2} \mathrm{Zn}_{2} \mathrm{Et}_{2}(\mathrm{THF})\left(\mathrm{L}=\mathrm{D}(2,6-\mathrm{Xyl}) \mathrm{F}\right.$ in 3 or $\mathrm{D}\left(2-{ }^{i} \mathrm{PrPh}\right) \mathrm{F}$ in $\left.\mathbf{4}\right)+$ $2 \mathrm{C}_{2} \mathrm{H}_{6}$

When reactions between $\mathrm{D}(3,5-\mathrm{Xyl}) \mathrm{FH}$ and $\mathrm{ZnEt}_{2}$ during the synthesis of complex 2 were contaminated with atmospheric oxygen or moisture, crystals of an oxygenated tetranuclear zinc cluster $[\mathrm{D}(3,5-\mathrm{Xyl}) \mathrm{F}]_{6} \mathrm{Zn}_{4}\left(\mu^{4}-\mathrm{O}\right)(\mathbf{5})$ were obtained as a byproduct. Proposed reactions leading to the formation of $\mathbf{5}$ are shown in Eq. 3 or 4. 
Crystals of 5, verified by cell determination in X-ray diffraction, were obtained reproducibly, indicating that the $\mathrm{Zn}$ complex 2 may be oxophilic or the oxygenated tetranuclear cluster 5 thermodynamically stable.

$$
\begin{aligned}
& 6 \mathrm{D}(3,5-\mathrm{Xyl}) \mathrm{FH}+4 \mathrm{ZnEt}_{2}+\mathrm{O}_{2} \rightarrow[\mathrm{D}(3,5-\mathrm{Xyl}) \mathrm{F}]_{6} \mathrm{Zn}_{4}\left(\mu^{4}-\mathrm{O}\right)(\mathbf{5})+6 \mathrm{C}_{2} \mathrm{H}_{6}+\mathrm{Et}_{2} \mathrm{O} \\
& 6 \mathrm{D}(3,5-\mathrm{Xyl}) \mathrm{FH}+4 \mathrm{ZnEt}_{2}+\mathrm{H}_{2} \mathrm{O} \rightarrow[\mathrm{D}(3,5-\mathrm{Xyl}) \mathrm{F}]_{6} \mathrm{Zn}_{4}\left(\mu^{4}-\mathrm{O}\right)(\mathbf{5})+8 \mathrm{C}_{2} \mathrm{H}_{6}
\end{aligned}
$$

Reactions between an even bulkier ligand $\mathrm{D}\left(2-{ }^{t} \mathrm{BuPh}\right) \mathrm{FH}$ and diethylzinc were also explored at similar reaction conditions; however, no quality crystals were obtained at various crystallization conditions. This was most likely due to the great size of the tertbutyl groups on the $\mathrm{D}\left(2-{ }^{t} \mathrm{BuPh}\right) \mathrm{FH}$ ligand that prevented the coordination of the $\mathrm{Zn}$ metal.

\subsection{Structural Analysis}

Molecular structures of the $\mathrm{Zn}$ complexes 1-5 were determined by single-crystal X-ray diffraction (Figures 3-5). Structural comparison of the five $\mathrm{Zn}$ complexes demonstrated their structural complexity and diverse nuclearities. Complexes $\mathbf{1}$ and $\mathbf{2}$ were trinuclear complexes while complexes $\mathbf{3}$ and $\mathbf{4}$ were dinuclear complexes. $\mathbf{5}$ was a tetranuclear zinc cluster with an interstitial oxide. Furthermore, the ligand-to-metal ratio was also altered between the complexes with different geometries. Detailed structure analysis is provided below in order to identify factors controlling the geometry of the products and the coordination modes of the ligands.

\subsubsection{Trinuclear Clusters}

As shown in Figure 3, both complexes $(\mathrm{DPhF})_{4} \mathrm{Zn}_{3} \mathrm{Et}_{2}$ (1) and $[\mathrm{D}(3,5-$ $\mathrm{Xyl}) \mathrm{F}]_{4} Z_{3} \mathrm{Et}_{2}(2)$ were trinuclear clusters with very similar structural geometry and the same ligand-to-metal ratio of 4:3. Compound $\mathbf{1}$ crystalized out in a $P 2_{1} / \mathrm{c}$ space group while compound 2 in a $P 4_{1} 2_{1} 2$ space group. In both cases, each unit cell comprised four 
trinuclear clusters. The asymmetric unit in $\mathbf{1}$ contained a single trinuclear cluster, while each trinuclear cluster of $\mathbf{2}$ bore a crystallographically imposed $C 2$ axis. Detailed comparison of structures and bond matrices of $\mathbf{1}$ and $\mathbf{2}$ (Figure 3 and Table 1) indicated that the geometries of both trinuclear clusters were nearly identical. Thus, cluster $\mathbf{1}$ should have an idealized $C 2$ axis going through the central $\mathrm{Zn} 2$ atom, where $\mathrm{Zn} 3$ and $\mathrm{Zn} 1$ atoms were related by the $\mathrm{C} 2$ axis. All zinc centers resided in a pseudo-tetrahedral environment with the $\mathrm{Zn} 2$ stabilized by four nitrogen donors from formamidinates and $\mathrm{Zn} 1$ or $\mathrm{Zn} 3$ by three nitrogen donors and one carbon atom from an ethyl group. Separation between the zinc atoms varied slightly with the central $\mathrm{Zn} 2$ atom in short distances of 3.1133(7) and 3.1065(7) $\AA$ to the other two $\mathrm{Zn}$ atoms, and the two symmetry-related $\mathrm{Zn}$ centers were further away from each other (Zn1' Zn3: 4.352(1) ̊̊). Very similar bond matrices with $\mathrm{Zn} \cdots \mathrm{Zn}$ separations of 3.1153(6) and 4.673(1) $\AA$ were observed in cluster 2 .

The formamidinate containing atom $\mathrm{C} 1$ or $\mathrm{C} 7$ in $\mathbf{1}$ bridged to two $\mathrm{Zn}$ centers with similar N-C bond lengths on the N-C-N backbone, ranging from 1.314(5)-1.322(5) $\AA$. In the other two formamidinates, a non-symmetric coordination mode VIII was observed where the N-C-N backbones were asymmetric, verified by the unequal N-C bond lengths. The short bond lengths of 1.308(5) and 1.299(5) A suggested the presence of an imine group while the longer bond lengths of 1.348(5) and 1.358(5) $\AA$ designated the amide groups. The anionic charges were localized on the amide $\mathrm{N}$ atoms (N3 and N6) that simultaneously bound two $\mathrm{Zn}$ atoms. The $\mathrm{N}$ atom on the imine group coordinated to a third $\mathrm{Zn}$ atom. The same non-symmetric coordination mode VIII was also observed for two formamidinates in cluster $\mathbf{2}$ in solid state. The other two formamidinates in $\mathbf{2}$ 
disclosed a coordination mode of $\mathbf{V}$ because variation in $\mathrm{N}-\mathrm{C}$ bond lengths was observed with C-N bond length of 1.334(4) $\AA$ for the amide and 1.304(4) $\AA$ for the imine group.

The asymmetric feature of the formamidinates in $\mathbf{1}$ and $\mathbf{2}$ was also observed in ${ }^{1} \mathrm{H}$ and ${ }^{13} \mathrm{C}$ NMR studies (Figures $1 \mathrm{~S}-4 \mathrm{~S}$ in the supporting information). Two sets of signals were observed for the $\mathrm{Hs}$ or $\mathrm{Cs}$ on the $\mathrm{N}-\mathrm{C}-\mathrm{N}$ backbones. Four sets of signals were observed for the Hs or Cs on the aromatic rings. Therefore, all DArF ligands in both 1 and $\mathbf{2}$ were in non-symmetric coordination modes $\mathbf{V}$ and VIII in solution phase, which should be true in solid state as well. The averaged $\mathrm{C}-\mathrm{N}$ distances in the two formamidinates containing atom $\mathrm{C} 1$ or $\mathrm{C} 7$ in $\mathbf{1}$ obtained from X-ray diffraction are probably due to disorder generated from packing.

\subsubsection{Dinuclear Complexes}

Greater steric hindrance was introduced by installing two methyl groups or an isopropyl group in the ortho position on each phenyl ring of the DArF ligands. Two dizinc complexes $[\mathrm{D}(2,6-\mathrm{Xyl}) \mathrm{F}]_{2} \mathrm{Zn}_{2} \mathrm{Et}_{2}(\mathrm{THF}), \mathbf{3}$ and $\left[\mathrm{D}\left(2{ }^{i}{ }^{i} \mathrm{PrPh}\right) \mathrm{F}\right]_{2} \mathrm{Zn}_{2} \mathrm{Et}_{2}(\mathrm{THF}), \mathbf{4}$ were synthesized as shown in Figure 4. In both complexes, the formamidinates clamped two $\mathrm{Zn}$ atoms from the top and the bottom. There was an additional ethyl group on each $\mathrm{Zn}$ atom and an extra THF molecule was in close proximity to one of the $\mathrm{Zn}$ atoms from the side (2.162(2) $\AA$ in 3 or 2.168(6) $\AA$ in 4, Table 2). One Zn atom was in a pseudo-trigonal planar geometry, while the other $\mathrm{Zn}$ atom was in a pseudo-tetrahedral geometry. The formamidinate ligands were cis to each other, resulting in a pseudo-paddlewheel geometry. Similar geometry has been observed in Li formamidinate complexes. ${ }^{12 \mathrm{~d}}$ NMR analysis (Figures 5S-8S), displaying only one set of NMR signals for both $\mathbf{3}$ and $\mathbf{4}$, indicated that the THF molecules were probably labile in solution. Most N-C bonds on 
the N-C-N backbones in both 3 and $\mathbf{4}$ were similar in length, ranging from 1.310(10) to 1.335(10) $\AA$. The small difference could be neglected because of detection deviations. Both formamidinates displayed coordination mode III, consistent with solution NMR analysis mentioned above. The $\mathrm{N}-\mathrm{Zn} \cdots \mathrm{Zn}-\mathrm{N}$ torsion angles $\left(22.8(3)^{\circ}\right.$ and $\left.20.8(3)^{\circ}\right)$ in 4 were much greater than those in $3\left(1.91(10)^{\circ}\right.$ and $\left.-5.76(10)^{\circ}\right)$, presumably due to steric hindrance from the iso-propyl groups on $\mathrm{D}\left(2-{ }^{i} \mathrm{PrPh}\right) \mathrm{F}$ in 4 . The increase in $\mathrm{N}-\mathrm{Zn} \cdots \mathrm{Zn}-\mathrm{N}$ torsion angles resulting from the greater steric demands of the ligands was clearly illustrated in Figure 4. It was likely that the unusual dizinc complexes $\mathbf{3}$ and $\mathbf{4}$ owed their stability to the presence of the substituents at the ortho positions.

An even bulkier ligand with two iso-propyl groups on the ortho positions of the aryl rings on the formamidinates produced a homoleptic monozinc complex $\left\{\mathrm{HC}(\mathrm{NDipp})_{2}\right\}_{2} \mathrm{Zn}$, in which each $\mathrm{Zn}$ atom was stabilized by two formamidinates. ${ }^{\text {Error! }}$ Bookmark not defined. Further increased steric demands of the ligand was achieved by replacing the substituents with tert-butyl groups, such as $\mathrm{D}\left(2{ }^{t} \mathrm{BuPh}\right) \mathrm{FH}$, did not lead to any clean product. Comparing the metallation reactions in this study and the complex $\left\{\mathrm{HC}(\mathrm{NDipp})_{2}\right\}_{2} \mathrm{Zn}$ indicated that as the steric hindrance of the DArF ligands increased, the nuclearity of $\mathrm{Zn}$ product complexes decreased from trinuclear, to dinuclear, to mononuclear, and finally no product was observed. Thus, steric properties of the ligand played a very important role in directly governing the structure and nuclearity of the product. This phenomenon has also been demonstrated in the syntheses of $\mathrm{Cr}$ formamidinate complexes. ${ }^{19}$ 
The separation between the two Zn atoms in $\mathbf{3}$ was $2.9737(5) \AA$, whereas $2.958(2)$ $\AA$ in 4. Both distances were much greater than the first reported $\mathrm{Zn}-\mathrm{Zn}$ single bond length of $\sim 2.305(3) \AA{ }^{20}$ and slightly longer than the sum of van der Waals radii for $\mathrm{Zn}-\mathrm{Zn}(2.78$ $\AA$ A), ${ }^{21}$ which indicate no net bonding between the two $\mathrm{Zn}$ centers in $\mathbf{3}$ and $\mathbf{4}$. The result was consistent with the fact that the $d^{10}$ electronic configuration for each $\mathrm{Zn}^{2+}$ ion precluded the presence of metal-metal bonding. The proximity of the metal ions was most likely enforced by the two bridging formamidinates.

\subsubsection{Tetranuclear Complexes}

The structure of cluster 5, shown in Figure 5, was similar to that of the basic zinc, ${ }^{22}$ dicarboxylate bridged tetrazinc oxide ${ }^{23}$ formamidinate bridged tetrazinc oxide ${ }^{\text {Error! }}$ Bookmark not defined. or basic beryllium acetate. ${ }^{24}$ It consisted of an oxygen atom at a tetrahedral center composed by four $\mathrm{Zn}$ metal atoms. Each unit cell in a space group of Pa-3 contained eight molecules of 5, each of which resided on a $C 3$ axis. Each asymmetric unit contained two $\mathrm{Zn}$ atoms with one $\mathrm{Zn}$ atom on a $C 3$ axis that further extended to the center of the right triangular formed by the other $\mathrm{Zn}$ atom and the two symmetry-generated $\mathrm{Zn}$ atoms. All N-C bond lengths on the N-C-N backbones were similar to each other ranging from $1.320(5)$ to $1.324(5) \AA$ (Table 3 ), indicating the possible coordination mode of III in all formamidinates in $\mathbf{5}$.

Each $\mathrm{Zn}$ atom was tetrahedrally coordinated, through coordination to the central oxygen atom and nitrogen atoms from three DArF ligands. Each ligand formed a bridge to each of the other three $\mathrm{Zn}$ atoms along the six edges of the $\left[\mathrm{Zn}_{4} \mathrm{O}\right]^{6+}$ unit as seen in the left graph of Figure 5. The four $\mathrm{Zn}$ metals were in a quite symmetric tetrahedral arrangement with non-bonded $\mathrm{Zn} \cdots \mathrm{Zn}$ distances varying slightly from $3.1312(8) \AA$ to 
3.1331(8) A. The Zn-O bond lengths in 5 (1.918(4)-1.9179(15) A) were close to those reported for similar complexes, as were the $\mathrm{Zn}-\mathrm{N}$ distances (2.018(3)-2.029(3) $\AA$ ). ${ }^{17}$ The ring structure $\mathrm{M}-\mathrm{N}-\mathrm{C}-\mathrm{N}-\mathrm{M}(\mathrm{M}=$ metal$)$ in most dinuclear complexes was nearly planar ${ }^{3}$ but in cluster 5, the two moieties (Zn1, N2, C1, N1, Zn2 and Zn2, N3, C18, N4, Zn2A) and its symmetry-generated M-N-C-N-M rings were all non-planar. The non-planarity has also been observed in other metal oxides where there were large $\mathrm{M}{ }^{\cdots} \mathrm{M}$ separations. ${ }^{\text {Error! Bookmark not defined.,22-24 }}$ Cluster $\mathbf{5}$ was obtained as an impurity product during the synthesis of $\mathbf{2}$, thus no other characterization data was obtained.

\subsection{Reactivities}

All product complexes were thermally robust, however, were sensitive to air and moisture. Synthesis of these compounds should be conducted in an inert atmosphere with special attention. Decomposition of the product 2 was still observed with low oxygen content, leading to the formation of cluster $\mathbf{5}$. The cluster was reproducibly isolated. The source of the oxygen contamination was not conformed, but likely from atmospheric oxygen or moisture content in the glove box. This phenomenon was similar to the formation of tetra-zinc clusters in $\mathrm{Zn}$ amidinate complexes where clusters $\left[\left\{\mathrm{HC}(\mathrm{NDipp})_{2}\right\} \mathrm{Zn}_{2} \mathrm{Et}_{2}\right]_{2} \mathrm{O},{ }^{15} \quad\left[\left\{\mathrm{HC}(\mathrm{NR})_{2}\right\}_{6} \mathrm{Zn}_{4}\right] \mathrm{O} \quad(\mathrm{R} \quad=\quad \mathrm{Ph}, \quad p$-Tol $),{ }^{17}$ $\left[\left\{\mathrm{MeC}(\mathrm{NDipp})_{2}\right\}_{2} \mathrm{Zn}_{2} \mathrm{R}_{2}\right]_{2} \mathrm{O}(\mathrm{R}=\mathrm{Me}, \mathrm{Et})^{18}$ and have been observed.

The synthesis of molecular compounds featuring bimetallic cores in close proximity has attracted great interest among inorganic chemists in terms of their cooperative reactivities. ${ }^{25}$ Dizinc complexes have shown interesting reactivities in which two Zinc centers cooperated and demonstrated interesting reactivities. ${ }^{26}$ Compounds $\mathbf{3}$ and $\mathbf{4}$ are great candidates for further study because they are the first two dizinc 
complexes with two $\mathrm{Zn}$ atoms relatively close in space, presenting great potential in cooperative reactivities of the two zinc atoms. Reactivity tests of complexes $\mathbf{3}$ and $\mathbf{4}$ with various substrates are in progress.

\section{Conclusions}

A series of stable $\mathrm{Zn}$ complexes (1-4) supported by $\mathrm{DArF}$ ligands were synthesized and characterized. Varied coordination modes III, V, and VIII were demonstrated by the DArF ligands in the complexes. Structural analysis indicated that bulkiness of the substituents on the ligands strongly influenced the success of the reaction and the geometry and nuclearity of the resulting $\mathrm{Zn}$ complexes. DArFs with no or less bulky substituents tended to stabilize products with high metal nuclearity (> 2), while DArFs with bulky substituents such as an iso-propyl group or two methyl groups at the ortho-positions of the aryl rings produced dizinc complexes. This study, together with the monozinc complex $\left\{\mathrm{HC}(\mathrm{NDipp})_{2}\right\}_{2} \mathrm{Zn}$ in the literature, indicated that that the increase in steric demands of the ligands decreased the nuclearity of the $\mathrm{Zn}$-formamidinate complexes. Further increase of the bulkiness of the ligand through the introduction of tert-butyl groups did not lead to any observed product. A tetranuclear cluster $\mathbf{5}$ with an interstitial oxide was obtained when a small amount of oxygen content was present during the synthesis of $\mathbf{2}$.

\section{Experimental Section}

General procedures. All manipulations were carried out using glove-box techniques in a nitrogen atmosphere. Glassware was oven-dried at $150^{\circ} \mathrm{C}$ for a minimum of $10 \mathrm{~h}$ and cooled in an evacuated antechamber prior to use in the glove box. Hexanes and THF were 
dried and deoxygenated on a Glass Contour System (SG Water USA, Nashua, NH) and stored over $4 \AA$ molecular sieves (Strem) prior to use. Chloroform- $d_{1}$ was purchased from Cambridge Isotope Labs, degassed and stored over $4 \AA$ molecular sieves in the glove box prior to use. Non-halogenated solvents were typically tested with a standard purple solution of sodium benzophenone ketyl in THF in order to confirm effective oxygen and moisture removal. All $N, N^{\prime}$-diarylformamidine ligands were prepared, following a procedure in the literature. ${ }^{4}$ All other reagents were purchased from commercial vendors and used without further purification unless explicitly stated.

\subsection{Synthesis}

$(\mathbf{D P h F})_{\mathbf{4}} \mathbf{Z n}_{\mathbf{3}} \mathbf{E t}_{\mathbf{2}}$ (1). $1.39 \mathrm{~g} 1.0 \mathrm{M}$ Diethylzinc in hexanes $(1.91 \mathrm{mmol})$ and $0.500 \mathrm{~g}$ $\mathrm{DPhFH}(2.55 \mathrm{mmol})$ were mixed in $10 \mathrm{~mL}$ of $\mathrm{THF}$ at $-35^{\circ} \mathrm{C}$, giving a light yellow solution upon stirring, and an evolution of gas was observed. The mixture was stirred overnight at room temperature and concentrated down to $1.0 \mathrm{~mL}$ under vacuum. $3.0 \mathrm{~mL}$ hexanes were then added to the resulting light yellow milky mixture. After decanting, the white precipitate produced was washed with hexanes $(3 \times 1.0 \mathrm{~mL})$ and dried under vacuum to give 1 as a white powder. Isolated yield: $0.62 \mathrm{~g}, 94 \%$. Diffusion evaporation crystallization at room temperature was set up after dissolving $\mathbf{1}$ in THF with hexanes diffusing in. Clear block-shaped crystals suitable for X-ray diffraction study were produced in a week. ${ }^{1} \mathrm{H}$ NMR $\left(\mathrm{CDCl}_{3}, 600 \mathrm{MHz}, \delta, \mathrm{ppm}\right): 8.21(\mathrm{~s}, 2 \mathrm{H}, \mathrm{N}=\mathrm{CH}-\mathrm{NH}), 7.89$ $(\mathrm{s}, 2 \mathrm{H}, \mathrm{N}=\mathrm{CH}-\mathrm{NH}), 7.44(\mathrm{~d}, 4 \mathrm{H}$, aromatic $p-\mathrm{C}-H), 7.21(\mathrm{~d}, 4 \mathrm{H}$, aromatic $p-\mathrm{C}-H), 6.62(\mathrm{~d}$, $4 \mathrm{H}$, aromatic $p-\mathrm{C}-\mathrm{H}), 5.64(\mathrm{~d}, 4 \mathrm{H}$, aromatic $p-\mathrm{C}-H), 7.37(\mathrm{t}, 4 \mathrm{H}$, aromatic $m-\mathrm{C}-H)$, 7.36(t, 4H, aromatic $m-\mathrm{C}-H), 7.04(\mathrm{t}, 4 \mathrm{H}$, aromatic $m-\mathrm{C}-H), 6.40(\mathrm{t}, 4 \mathrm{H}$, aromatic $m-\mathrm{C}-$ $H), 7.19(\mathrm{t}, 2 \mathrm{H}$, aromatic $o-\mathrm{C}-H), 7.17(\mathrm{t}, 2 \mathrm{H}$, aromatic $o-\mathrm{C}-H), 7.03(\mathrm{t}, 2 \mathrm{H}$, aromatic $o-\mathrm{C}-$ 
$H$ ), $6.45(\mathrm{t}, 2 \mathrm{H}$, aromatic $o-\mathrm{C}-\mathrm{H}), 0.70\left(\mathrm{t}, 6 \mathrm{H}, \mathrm{Zn}-\mathrm{CH}_{2}-\mathrm{CH}_{3}\right),-0.04$ (q, $4 \mathrm{H}, \mathrm{Zn}-\mathrm{CH}_{2}-$ $\left.\mathrm{CH}_{3}\right) .{ }^{13} \mathrm{C} \mathrm{NMR}\left(\mathrm{CDCl}_{3}, 150 \mathrm{MHz}, \delta, \mathrm{ppm}\right): 168.6,166.0,150.6,149.6,149.0,148.7$, $129.5,129.3,128.8,127.92,125.0,124.6,124.4,124.3,124.2,123.9,123.4,123.3,13.2$, 2.2. Anal. Calcd. for $\mathrm{C}_{56} \mathrm{H}_{54} \mathrm{~N}_{8} \mathrm{Zn}_{3}(\mathbf{1})$ : C, 64.97; H, 5.26; N, 10.82\%. Found: C, 65.05; H, $5.34 ; \mathrm{N}, 10.87 \%$.

[D(3,5-Xyl)F $]_{4} \mathbf{Z n}_{3} \mathbf{E t}_{\mathbf{2}}$ (2). $0.386 \mathrm{~g} 1.0 \mathrm{M}$ diethylzinc in hexanes $(1.20 \mathrm{mmol})$ and $0.200 \mathrm{~g}$ $\mathrm{D}(3,5-\mathrm{Xyl}) \mathrm{FH}(0.79 \mathrm{mmol})$ were mixed in $10 \mathrm{~mL}$ of $\mathrm{THF}$ at $-35^{\circ} \mathrm{C}$, giving a light yellow solution upon stirring, and an evolution of gas was observed. The mixture was stirred overnight at room temperature and concentrated down to $1.0 \mathrm{~mL}$ under vacuum. The resulting light yellow milky solution with white precipitate was washed with hexanes (3 $\times 1.0 \mathrm{~mL}$ ) and dried under vacuum to give 2 as a white powder. Isolated yield: $0.21 \mathrm{~g}$, 93\%. Diffusion evaporation crystallization at room temperature was set up using a product solution in THF with hexanes diffusing in, slowly producing clear block-shaped crystals suitable for X-ray diffraction studies. ${ }^{1} \mathrm{H}$ NMR $\left(\mathrm{CDCl}_{3}, 600 \mathrm{MHz}, \delta, \mathrm{ppm}\right)$ : 8.07(s, 2H, N-CH-N), 7.86(s, 2H, N-CH-N), 7.03(s, 4H, aromatic $m-\mathrm{C}-H), 6.87(\mathrm{~s}, 4 \mathrm{H}$, aromatic $m-\mathrm{C}-H), 6.18(\mathrm{~s}, 4 \mathrm{H}$, aromatic $m-\mathrm{C}-H), 5.40(\mathrm{~s}, 4 \mathrm{H}$, aromatic $m-\mathrm{C}-H), 6.85(\mathrm{~s}$, $2 \mathrm{H}$, aromatic o-C $-H), 6.79(\mathrm{~s}, 2 \mathrm{H}$, aromatic o-C $-H), 6.68(\mathrm{~s}, 2 \mathrm{H}$, aromatic o-C $-H), 6.12$ (s, $2 \mathrm{H}$, aromatic o-C-H), 2.33(s, $\left.12 \mathrm{H}, \mathrm{Ar}-\mathrm{CH}_{3}\right), 2.31\left(\mathrm{~s}, 12 \mathrm{H}, \mathrm{Ar}-\mathrm{CH}_{3}\right), 2.02(\mathrm{~s}, 12 \mathrm{H}, \mathrm{Ar}-$ $\left.\mathrm{CH}_{3}\right), 1.80\left(\mathrm{~s}, 12 \mathrm{H}, \mathrm{Ar}-\mathrm{CH}_{3}\right), 0.72\left(\mathrm{t}, 6 \mathrm{H}, \mathrm{Zn}-\mathrm{CH}_{2}-\mathrm{CH}_{3}\right),-0.06$ (dq, $\left.4 \mathrm{H}, \mathrm{Zn}-\mathrm{CH}_{2}-\mathrm{CH}_{3}\right)$. ${ }^{13} \mathrm{C}$ NMR $\left(\mathrm{CDCl}_{3}, 150 \mathrm{MHz}, \delta, \mathrm{ppm}\right): 167.5,165.0,150.7,149.5,149.4,148.8,138.9$, $138.7,138.1,137.1,126.1,125.6,125.5,124.7,122.4,122.3,121.9,121.6,21.66,21.43$, 20.96, 20.91, 13.06, 2.85. Anal. Calcd. for $\mathrm{C}_{72} \mathrm{H}_{86} \mathrm{~N}_{8} \mathrm{Zn}_{3}$ (2). Cal: C, 68.65; H, 6.88; N, 8.90\%. Found: C, 68.47; H, 6.94; N, 8.81\%. 
$[\mathbf{D}(\mathbf{2 , 6}-\mathbf{X y l}) \mathbf{F}]_{2} \mathbf{Z n}_{2} \mathbf{E t}_{2}$ (THF) (3). 0.288 g 1.0 M diethylzinc in hexanes (3.96 mmol) and $1.0 \mathrm{~g} \mathrm{D}(2,6-\mathrm{Xyl}) \mathrm{FH}(3.96 \mathrm{mmol})$ were mixed in $10 . \mathrm{mL}$ of $\mathrm{THF}$ at $-35^{\circ} \mathrm{C}$, giving a light yellow solution upon stirring, and an evolution of gas was observed. The mixture was stirred overnight at room temperature. Diffusion evaporation crystallization at room temperature was set up in THF solution with hexanes diffusing in, slowly producing block-shaped clear crystals suitable for X-ray diffraction studies. The resulting crystals was collected by a frit, washed with hexanes $(2 \times 8.0 \mathrm{~mL})$ and dried under vacuum. Crystal yield: $0.44 \mathrm{~g}, 15 \% .{ }^{1} \mathrm{H} \mathrm{NMR}\left(\mathrm{CDCl}_{3}, 150 \mathrm{MHz}, \delta, \mathrm{ppm}\right): 7.33$ (s, 2H, N-CH-N), $6.96(\mathrm{~d}, 8 \mathrm{H}$, aromatic $m-\mathrm{C}-\mathrm{H}), 6.90(\mathrm{t}, 4 \mathrm{H}$, aromatic $o-\mathrm{C}-\mathrm{H}), 3.51\left(\mathrm{~b}, 4 \mathrm{H}, \mathrm{O}-\mathrm{CH}_{2}-\mathrm{CH}_{2}\right.$ in THF), 2.24 (s, 24H, Ar- $\left.\mathrm{CH}_{3}\right) 1.71$ (b, 4H, $\mathrm{CH}_{2}-\mathrm{CH}_{2}-\mathrm{CH}_{2}$ in THF), 0.91 (t, 6H, $\mathrm{Zn}-\mathrm{CH}_{2}-$ $\left.\mathrm{CH}_{3}\right), 0.25\left(\mathrm{q}, 4 \mathrm{H}, \mathrm{Zn}-\mathrm{CH}_{2}-\mathrm{CH}_{3}\right) .{ }^{13} \mathrm{C} \mathrm{NMR}\left(\mathrm{CDCl}_{3}, 150 \mathrm{MHz}, \delta, \mathrm{ppm}\right): 165.6,146.8$, 133.7, 128.4, 124.7, 68.4, 25.5, 19.7, 12.4, 1.75. Anal. Calcd. for $\mathrm{C}_{42} \mathrm{H}_{56} \mathrm{~N}_{4} \mathrm{OZn}_{2}(3)$ : C, 66.06; H, 7.39; N, 7.34\%. Found: C, 65.68; H, 7.35; N, 7.06\%.

[D(2- $\left.\left.{ }^{i} \mathbf{P r P h}\right) \mathbf{F}\right]_{2} \mathbf{Z n}_{2} \mathbf{E t}_{2}$ (THF) (4). $0.717 \mathrm{~g} 1.0 \mathrm{M}$ Diethylzinc $(0.79 \mathrm{mmol})$ and $0.200 \mathrm{~g}$ $\mathrm{D}\left(2-{ }^{\mathrm{i}} \mathrm{PrPh}\right) \mathrm{FH}(0.79 \mathrm{mmol})$ were mixed in $10 . \mathrm{mL}$ of $\mathrm{THF}$ at $-35^{\circ} \mathrm{C}$, giving a light yellow solution upon stirring, and an evolution of gas was observed. The mixture was stirred overnight at room temperature, and concentrated down to $1.0 \mathrm{~mL}$ under vacuum. The resulting light yellow milky solution with white precipitate was washed with hexanes (3 $\times 1.0 \mathrm{~mL}$ ) and dried under vacuum to give 4 as a white powder. Isolated yield: $0.23 \mathrm{~g}$, 54\%. Diffusion evaporation crystallization at $-30^{\circ} \mathrm{C}$ was set up in THF solution with hexanes diffusing in, slowly producing clear block-shaped crystals suitable for X-ray diffraction studies. ${ }^{1} \mathrm{H}$ NMR $\left(\mathrm{CDCl}_{3}, 600 \mathrm{MHz}, \delta, \mathrm{ppm}\right): 7.65$ (s, 2H, N-CH-N), 7.21 (d, 4H, aromatic C-H), $7.09(\mathrm{t}, 4 \mathrm{H}$, aromatic $\mathrm{C}-H), 7.06(\mathrm{t}, 4 \mathrm{H}$, aromatic $\mathrm{C}-H), 6.79(\mathrm{~d}, 4 \mathrm{H}$, 
aromatic $\left.\mathrm{C}-H), 3.68\left(\mathrm{~b}, 4 \mathrm{H}, \mathrm{O}-\mathrm{CH}_{2}-\mathrm{CH}_{2} \text { in THF), } 3.29 \text { (sep, 4H, C-CH-( } \mathrm{CH}_{3}\right)_{2}\right), 1.80$ (b, $4 \mathrm{H}, \mathrm{CH}_{2}-\mathrm{CH}_{2}-\mathrm{CH}_{2}$ in THF), 1.11 (d, $\left.24 \mathrm{H},-\mathrm{CH}-\left(\mathrm{CH}_{3}\right)_{2}\right), 1.07$ (t, $\left.6 \mathrm{H}, \mathrm{Zn}-\mathrm{CH}_{2}-\mathrm{CH}_{3}\right)$, 0.39 (q, $\left.4 \mathrm{H}, \mathrm{Zn}-\mathrm{CH}_{2}-\mathrm{CH}_{3}\right) .{ }^{13} \mathrm{C} \mathrm{NMR}\left(\mathrm{CDCl}_{3}, 150 \mathrm{MHz}, \delta, \mathrm{ppm}\right): 163.8,146.4,143.0$, $126.4,126.1,125.6,125.1,68.3,28.2,25.6,23.9,12.2,1.42$.

$[\mathbf{D}(\mathbf{3 , 5}-\mathbf{X y l}) \mathbf{F}]_{6} \mathbf{Z n}_{4}\left(\mu^{4}-\mathbf{O}\right)(\mathbf{5})$. The procedure was the same as that of complex $\mathbf{2}$, but in the presence of residual oxygen content, cluster 5 formed instead. Diffusion evaporation crystallization at room temperature was set up in THF solution with hexanes diffusing in, slowly producing clear block-shaped crystals suitable for X-ray diffraction studies. Crystals of the same unit cell were observed multiple times.

\subsection{X-ray Structure Determinations}

Crystals were carefully sealed with Teflon- and Para-film in a capped vial and stored in a $\mathrm{N}_{2}$ filled zip-lock bag before being shipped out for analysis. Single crystals suitable for X-ray analysis were coated with deoxygenated Paratone-N oil and mounted on Kaptan loops. Crystallographic Data for compounds 1, 3 and 5 were collected at 100 $\mathrm{K}$ on a Siemens (Bruker) SMART CCD area detector instrument with Mo $K \square$ radiation. Crystallographic Data for compounds $\mathbf{2}$ and $\mathbf{4}$ were collected on Beamline 11.3.1 at the Advanced Light Source, Lawrence Berkeley National Lab using monochromatic radiation $(\lambda=0.7749 \AA)$ at $150(2) \mathrm{K}$. Raw data was integrated and corrected for Lorentz and polarization effects using Bruker APEX2 v. 2009.1. ${ }^{27}$ Absorption corrections were applied using SADABS. ${ }^{28}$ Space group assignments were determined by examination of systematic absences, E-statistics, and successive refinement of the structures. The program PLATON ${ }^{29}$ was employed to confirm the absence of higher symmetry for any of the crystals. The position of the heavy atoms was determined using direct methods in the 
program SHELXTL. ${ }^{30}$ Subsequent cycles of least-squares refinement followed by difference Fourier syntheses revealed the positions of the remaining non-hydrogen atoms. Non-hydrogen atoms, excluding the THF solvent molecules in compound $\mathbf{5}$ were refined with anisotropic displacement parameters, and hydrogen atoms were added in idealized positions. Selected distances, bond angles and torsion angles are shown in Tables 1-3. Crystallographic data was shown in Table 4. Figures of X-ray crystal structures of complexes 1, 3, 4 and 5 (Figures 3-5) were generated from Ortep-3 for Windows ${ }^{31}$ and rendered using POV-Ray v3.6 for Windows. ${ }^{32}$ Figures of X-ray crystal structures of complex 2 (Figure 3) were generated from XP in SHELXTL. ${ }^{30}$

\subsection{Other Physical Measurements}

Elemental analyses were performed by Complete Analysis Laboratories, Inc., Parsippany, New Jersey. ${ }^{1} \mathrm{H}$ NMR and ${ }^{13} \mathrm{C}$ NMR spectra were acquired on JEOL ECA$600 \mathrm{NMR}$-spectrometer $\left(600 \mathrm{MHz}\right.$ for ${ }^{1} \mathrm{H}$ and $150 \mathrm{MHz}$ for ${ }^{13} \mathrm{C}$ ) with spinning at $\mathrm{rt}$. Samples were sealed in a nitrogen environment before being sent for measurements.

\section{Appendix A. Supplementary data}

NMR spectra of complexes 1-4 were provided as supplementary data associated with this article, which can be found in the online version, at link xxxx. CCDC 1033764 (1), $1033765(\mathbf{2}), 1033766(3), 1033767(4)$ and 1033768 (5) contain the supplementary crystallographic data for this paper. This data can be obtained free of charge via http://www.ccdc.cam.ac.uk/conts/retrieving.html, or from the Cambridge Crystallographic Data Centre, 12 Union Road, Cambridge CB2 1EZ, UK; fax: (+44) 1223-336-033; or e-mail: deposit@ccdc.cam.ac.uk. 


\section{Acknowledgements}

We thank Dr. Vyacheslav V. Samoshin for the NMR measurements, Dr. Simon J. Teat for his help with single crystal measurements of compounds $\mathbf{2}$ and $\mathbf{4}$, and Michael B. Pastor for manuscript editing. We gratefully acknowledge the support from the Department of Chemistry, Pacific Fund and SAAG Grant at University of the Pacific, the NSF Major Research Instrumentation Grant (CHE-0722654) for the funding of JEOL ECA-600 NMR spectrometer, and the general user proposals for beam time at the Advanced Light Source of Lawrence Berkeley National Lab. The Advanced Light Source is supported by the Director, Office of Science, and Office of Basic Energy Sciences of the U.S. Department of Energy under Contract No. DE-AC02-05CH11231.

\section{Scheme 1.}

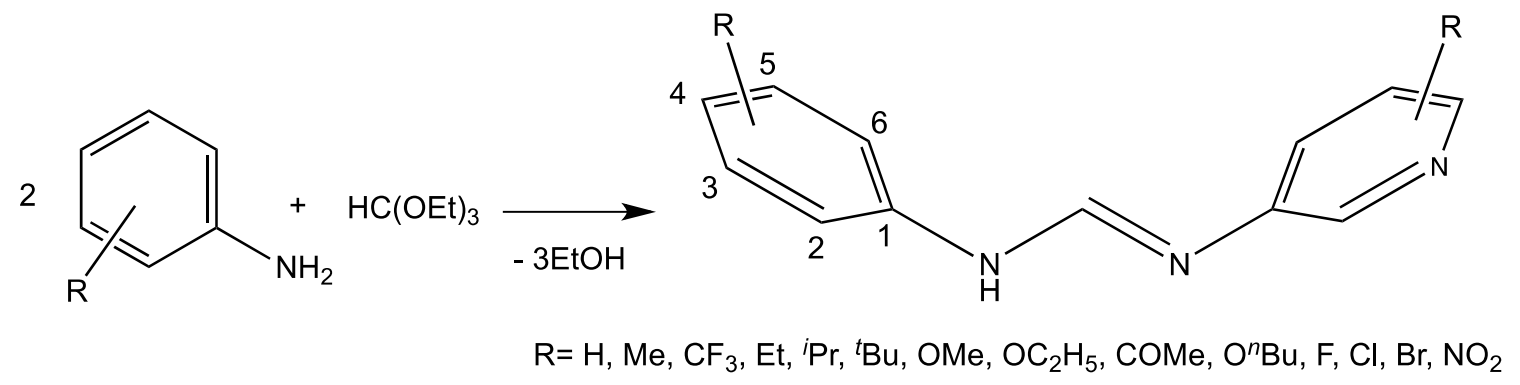


Table 1. Selected Distances $(\AA)$ and Angles (deg) in Complexes $\mathbf{1}$ and 2.

\begin{tabular}{|c|c|c|c|}
\hline & 1 & & 2 \\
\hline $\mathrm{Zn} 1 \cdots \mathrm{Zn} 2$ & $3.1133(7)$ & $\mathrm{Zn} 1 \cdots \mathrm{Zn} 2$ & $3.1153(6)$ \\
\hline $\mathrm{Zn} 2 \cdots \mathrm{Zn} 3$ & $3.1065(7)$ & & \\
\hline $\mathrm{Zn} 1 \cdots \mathrm{Zn} 3$ & $4.352(1)$ & $\mathrm{Zn} 1 \cdots \mathrm{Zn} 1 \mathrm{~A}$ & $4.673(1)$ \\
\hline Zn1-C91 & $1.982(4)$ & Zn1-C41 & $1.987(3)$ \\
\hline $\mathrm{Zn} 2-\mathrm{C} 93$ & $1.976(4)$ & & \\
\hline Zn1-N1 & $2.044(3)$ & $\mathrm{Zn} 1-\mathrm{N} 3$ & $2.042(3)$ \\
\hline Zn1-N5 & $2.062(4)$ & Zn1-N1 & $2.066(2)$ \\
\hline $\mathrm{Zn} 1-\mathrm{N} 3$ & $2.308(3)$ & $\mathrm{Zn} 1-\mathrm{N} 2 \mathrm{~A}$ & $2.341(2)$ \\
\hline $\mathrm{Zn} 2-\mathrm{N} 2$ & $1.990(4)$ & Zn2-N4 & $1.981(2)$ \\
\hline $\mathrm{Zn} 2-\mathrm{N} 6$ & $2.035(3)$ & $\mathrm{Zn} 2-\mathrm{N} 2$ & $2.035(2)$ \\
\hline Zn2-N7 & $1.985(3)$ & & \\
\hline $\mathrm{Zn} 2 \mathrm{~N} 3$ & $2.051(3)$ & & \\
\hline $\mathrm{Zn3-N4}$ & $2.063(3)$ & & \\
\hline Zn3-N6 & $2.275(4)$ & & \\
\hline $\mathrm{Zn3-N8}$ & $2.055(4)$ & & \\
\hline $\mathrm{C} 1-\mathrm{N} 1$ & $1.314(5)$ & $\mathrm{C} 21-\mathrm{N} 3$ & $1.334(4)$ \\
\hline $\mathrm{C} 1-\mathrm{N} 2$ & $1.322(5)$ & C21-N4 & $1.304(4)$ \\
\hline $\mathrm{C} 3-\mathrm{N} 3$ & $1.348(5)$ & & \\
\hline C3-N4 & $1.308(5)$ & & \\
\hline C5-N5 & $1.299(5)$ & C1-N1 & $1.305(4)$ \\
\hline C5-N6 & $1.358(5)$ & $\mathrm{C} 1-\mathrm{N} 2$ & $1.348(4)$ \\
\hline C7-N7 & $1.315(5)$ & & \\
\hline C7-N8 & $1.320(5)$ & & \\
\hline N1-C1-N2 & $125.6(4)$ & N3-C21-N4 & $126.3(3)$ \\
\hline $\mathrm{N} 3-\mathrm{C} 3-\mathrm{N} 4$ & $125.1(4)$ & & \\
\hline N5-C5-N6 & $124.4(4)$ & $\mathrm{N} 1-\mathrm{C} 1-\mathrm{N} 2$ & $125.2(3)$ \\
\hline N7-C7-N8 & $125.4(4)$ & & \\
\hline $\mathrm{Zn} 1-\mathrm{N} 3-\mathrm{Zn} 2$ & $90.97(12)$ & Zn1-N2A-Zn2 & $90.49(9)$ \\
\hline Zn2-N6-Zn3 & $92.06(13)$ & & \\
\hline
\end{tabular}


Table 2. Selected Distances ( $\AA$ ) and Angles (deg) in Complexes 3 and 4.

\begin{tabular}{lll}
\hline & $\mathbf{3}$ & $\mathbf{4}$ \\
\hline $\mathrm{Zn} 1 \cdots \mathrm{Zn} 2$ & $2.9737(5)$ & $2.958(2)$ \\
$\mathrm{Zn} 1-\mathrm{C} 43$ & $1.989(3)$ & $1.976(9)$ \\
$\mathrm{Zn} 2-\mathrm{C} 41$ & $2.024(3)$ & $2.020(8)$ \\
$\mathrm{Zn} 2-\mathrm{O} 1 \mathrm{~S}$ & $2.162(2)$ & $2.168(6)$ \\
$\mathrm{Zn} 1-\mathrm{N} 1$ & $2.030(2)$ & $2.000(7)$ \\
$\mathrm{Zn} 1-\mathrm{N} 3$ & $2.027(2)$ & $2.018(7)$ \\
$\mathrm{Zn} 2-\mathrm{N} 2$ & $2.010(2)$ & $2.070(6)$ \\
$\mathrm{Zn} 2-\mathrm{N} 4$ & $2.034(2)$ & $2.021(7)$ \\
$\mathrm{C} 1-\mathrm{N} 1$ & $1.315(3)$ & $1.335(10)$ \\
$\mathrm{C} 1-\mathrm{N} 2$ & $1.315(4)$ & $1.310(10)$ \\
$\mathrm{C} 21-\mathrm{N} 3$ & $1.320(4)$ & $1.323(10)$ \\
$\mathrm{C} 21-\mathrm{N} 4$ & $1.312(3)$ & $1.326(10)$ \\
$\mathrm{N} 1-\mathrm{C} 1-\mathrm{N} 2$ & $126.6(3)$ & $125.7(7)$ \\
$\mathrm{N} 3-\mathrm{C} 21-\mathrm{N} 4$ & $125.5(3)$ & $123.7(7)$ \\
$\mathrm{N} 1-\mathrm{Zn} 1-\mathrm{N} 3$ & $116.84(9)$ & $104.9(3)$ \\
$\mathrm{N} 2-\mathrm{Zn} 2-\mathrm{N} 4$ & $114.82(10)$ & $105.0(3)$ \\
$\mathrm{N} 1-\mathrm{Zn} 1 \cdots \mathrm{Zn} 2-\mathrm{N} 2$ & $1.91(10)$ & $22.8(3)$ \\
$\mathrm{N} 3-\mathrm{Zn} 1 \cdots \mathrm{Zn} 2-\mathrm{N} 4$ & $-5.76(10)$ & $20.8(3)$ \\
\hline
\end{tabular}


Table 3. Selected Distances $(\AA)$, Angles and Torsion Angles (deg) in Complex 5

\begin{tabular}{llll}
\hline $\mathrm{Zn} 1 \cdots \mathrm{Zn} 2$ & $3.1312(8)$ & $\mathrm{C} 1-\mathrm{N} 1$ & $1.322(5)$ \\
$\mathrm{Zn} 2 \cdots \mathrm{Zn} 2 \mathrm{~A}$ & $3.1331(8)$ & $\mathrm{C} 1-\mathrm{N} 2$ & $1.324(5)$ \\
$\mathrm{Zn} 1-\mathrm{O} 1$ & $1.918(4)$ & $\mathrm{C} 18-\mathrm{N} 3$ & $1.321(5)$ \\
$\mathrm{Zn} 2-\mathrm{O} 1$ & $1.9179(15)$ & $\mathrm{C} 18-\mathrm{N} 4$ & $1.320(5)$ \\
$\mathrm{Zn} 1-\mathrm{N} 2$ & $2.029(3)$ & $\mathrm{N} 1-\mathrm{C} 1-\mathrm{N} 2$ & $122.8(4)$ \\
$\mathrm{Zn} 2-\mathrm{N} 1$ & $2.020(3)$ & $\mathrm{N} 3-\mathrm{C} 18-\mathrm{N} 4$ & $123.1(4)$ \\
$\mathrm{Zn} 2-\mathrm{N} 3$ & $2.018(3)$ & $\mathrm{Zn} 1-\mathrm{O} 1-\mathrm{Zn} 2$ & $109.41(12)$ \\
$\mathrm{Zn} 2-\mathrm{N} 4 \mathrm{~B}$ & $2.019(3)$ & $\mathrm{Zn} 2-\mathrm{O} 1-\mathrm{Zn} 2 \mathrm{~A}$ & $109.53(12)$ \\
& & $\mathrm{N} 1-\mathrm{Zn} 2 \cdots \mathrm{Zn} 1-\mathrm{N} 2$ & $-67.63(14)$ \\
& & $\mathrm{N} 3-\mathrm{Zn} 2 \cdots \mathrm{Zn} 2 \mathrm{~A}-\mathrm{N} 4$ & $43.1(1)$ \\
\hline
\end{tabular}


Table 4. Crystallographic Data of Zinc Complexes 1-5

\begin{tabular}{|c|c|c|c|c|c|}
\hline & $\mathbf{1}^{a}$ & $2^{b}$ & 3. $0.5 \mathrm{C}_{6} \mathrm{H}_{14}{ }^{a}$ & $4^{b}$ & $\mathbf{5 \cdot 1 . 7 4 \mathrm { THF } ^ { a }}$ \\
\hline $\begin{array}{l}\text { chemical } \\
\text { formula }\end{array}$ & $\begin{array}{l}\mathrm{C}_{56} \mathrm{H}_{54} \mathrm{~N}_{8} \mathrm{Z} \\
\mathrm{n}_{3}\end{array}$ & $\mathrm{C}_{72} \mathrm{H}_{86} \mathrm{~N}_{8} \mathrm{Zn}_{3}$ & $\begin{array}{l}\mathrm{C}_{45} \mathrm{H}_{63} \mathrm{~N}_{4} \mathrm{O} \\
\mathrm{Zn}_{2}\end{array}$ & $\begin{array}{l}\mathrm{C}_{46} \mathrm{H}_{64} \mathrm{~N}_{4} \mathrm{O} \\
\mathrm{Zn}_{2}\end{array}$ & $\begin{array}{l}\mathrm{C}_{108.96} \mathrm{H}_{127.9} \\
{ }_{2} \mathrm{~N}_{12} \mathrm{O}_{2.74} \\
\mathrm{Zn}_{4}\end{array}$ \\
\hline $\begin{array}{l}\text { formula } \\
\text { weight }\end{array}$ & 1035.18 & 1259.60 & 806.73 & 819.75 & 1911.71 \\
\hline$T, \mathrm{~K}$ & 100 & $150(2)$ & 100 & $150(2)$ & 100 \\
\hline $\begin{array}{l}\text { space } \\
\text { group }\end{array}$ & $P 2_{1} / \mathrm{c}$ & $P 4{ }_{1} 2{ }_{1} 2$ & $P 2_{1} / \mathrm{n}$ & $P-1$ & $P a-3$ \\
\hline$Z$ & 4 & 4 & 4 & 2 & 8 \\
\hline$a, \AA$ & $11.7075(9)$ & $14.246(2)$ & $12.259(1)$ & $11.009(5)$ & $27.3541(6)$ \\
\hline$b, \AA$ & $13.3734(9)$ & $14.246(2)$ & $22.560(2)$ & $12.222(6)$ & $27.3541(6)$ \\
\hline$c, \AA$ & $31.655(2)$ & $32.621(5)$ & $15.797(1)$ & $18.50(1)$ & $27.3541(6)$ \\
\hline$\alpha, \operatorname{deg}$ & 90 & 90 & 90 & $103.007(8)$ & 90 \\
\hline$\beta, \operatorname{deg}$ & $100.428(4)$ & 90 & $107.719(4)$ & $100.548(8)$ & 90 \\
\hline$\gamma, \operatorname{deg}$ & 90 & 90 & 90 & $110.395(6)$ & 90 \\
\hline$V, \AA^{3}$ & $4874.3(6)$ & $6620.1(18)$ & $4161.6(6)$ & $2178(2)$ & $20467.6(8)$ \\
\hline $\mathrm{D}_{\mathrm{c}}, \mathrm{g} \mathrm{cm}^{-3}$ & 1.411 & 1.264 & 1.288 & 1.250 & 1.241 \\
\hline $\begin{array}{l}R_{1}\left(w R_{2}\right)^{c} \\
\text { (all data) } \\
R_{1}\left(w R_{2}\right)^{c} \\
{[I>2 \sigma(I)]}\end{array}$ & $\begin{array}{l}0.1048(0.1 \\
192) \\
0.0488(0.0 \\
899)\end{array}$ & $\begin{array}{l}0.0430(0.105 \\
2) \\
0.0405 \\
(0.1036)\end{array}$ & $\begin{array}{l}0.0743(0.09 \\
51) \\
0.0419 \\
(0.0864)\end{array}$ & $\begin{array}{l}0.1058(0.27 \\
96) \\
0.0924 \\
(0.2704)\end{array}$ & $\begin{array}{l}0.0978(0.16 \\
46) \\
0.0555 \\
(0.1360)\end{array}$ \\
\hline $\begin{array}{l}\text { Goodness } \\
\text { of fit }\end{array}$ & 1.011 & 1.069 & 1.022 & 1.039 & 1.013 \\
\hline $\begin{array}{l}\text { deposition } \\
\text { No. }\end{array}$ & 1033764 & 1033765 & 1033766 & 1033767 & 1033768 \\
\hline
\end{tabular}

${ }^{a}$ Mo K $\alpha$ radiation. ${ }^{b}$ monochromatic radiation $(\lambda \square=0.7749 \AA)$.

${ }^{c} R_{1}=\square \Sigma|| F_{\mathrm{o}}|-| F_{\mathrm{c}}|| / \Sigma\left|F_{\mathrm{o}}\right| ; w R_{2}=\left\{\Sigma\left[w\left(F_{\mathrm{o}}{ }^{2}-F_{\mathrm{c}}{ }^{2}\right)^{2}\right] / \Sigma\left[w\left(\mathrm{~F}_{\mathrm{o}}{ }^{2}\right)^{2}\right]\right\}^{1 / 2}$. 
<smiles></smiles>

I<smiles></smiles>

V<smiles></smiles>

II

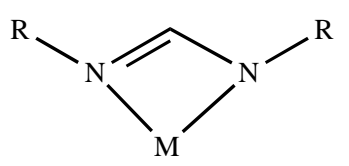

VI<smiles>[R]N1[Y14]=NN([R])C1</smiles>

III<smiles>[R]n1cn[Y]1([Y1])[R]</smiles>

VII<smiles>[R]N=CN([R])[M]</smiles>

IV



VIII

Figure 1. Various coordination modes of formamidine and formamidinates $(R=$ alkyl, aryl or silyl).<smiles>C(=N/c1ccccc1)\c1ccccc1</smiles>

$\mathrm{DPhFH}$<smiles>Cc1cc(C)cc(/N=C/Nc2cc(C)cc(C)c2)c1</smiles>

$\mathrm{D}(3,5-\mathrm{Xyl}) \mathrm{FH}$<smiles>Cc1cccc(C)c1/N=C/Nc1c(C)cccc1C</smiles>

$\mathrm{D}(2,6-\mathrm{Xyl}) \mathrm{FH}$<smiles>CC(C)c1ccccc1/N=C/Nc1ccccc1C(C)C</smiles>

$\mathrm{D}\left(2-{ }^{i} \mathrm{PrPh}\right) \mathrm{FH}$<smiles>CC(C)(C)c1ccccc1N=CNc1ccccc1C(C)(C)C</smiles>

$\mathrm{D}\left(2-{ }^{t} \mathrm{BuPh}\right) \mathrm{FH}$

Figure 2. Formamidines and their abbreviated names. 


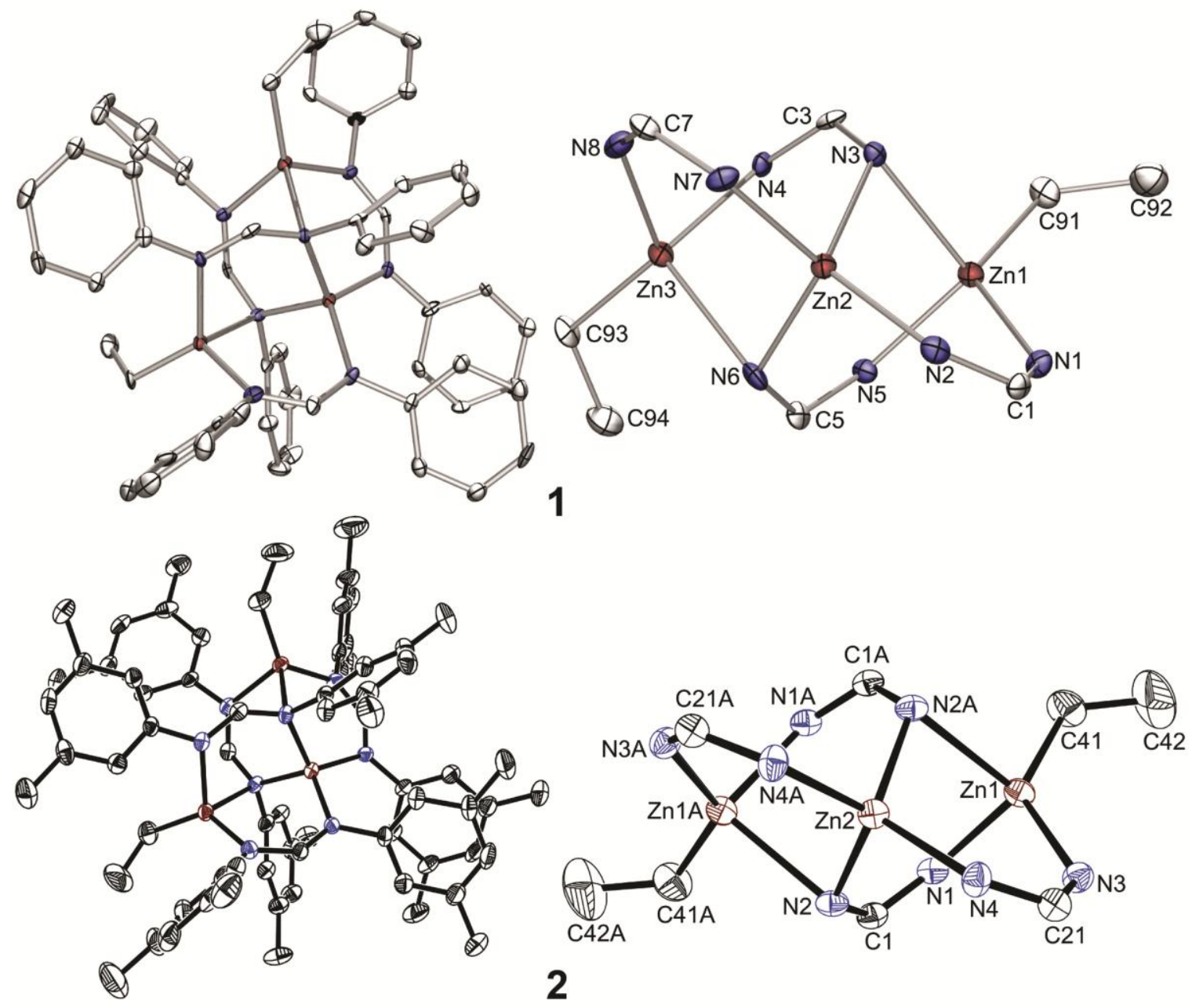

Figure 3. Left: X-ray crystal structures of 1 (top) and 2 (bottom). Hydrogen atoms are omitted for clarity. Right: Illustrations of the central cores in $\mathbf{1}$ (top) and $\mathbf{2}$ (bottom) showing the arrangement of the three $\mathrm{Zn}$ atoms and the distribution of DArF ligands. Aryl groups and hydrogen atoms are omitted for clarity. Ellipsoids are shown at the 50\% probability level. 

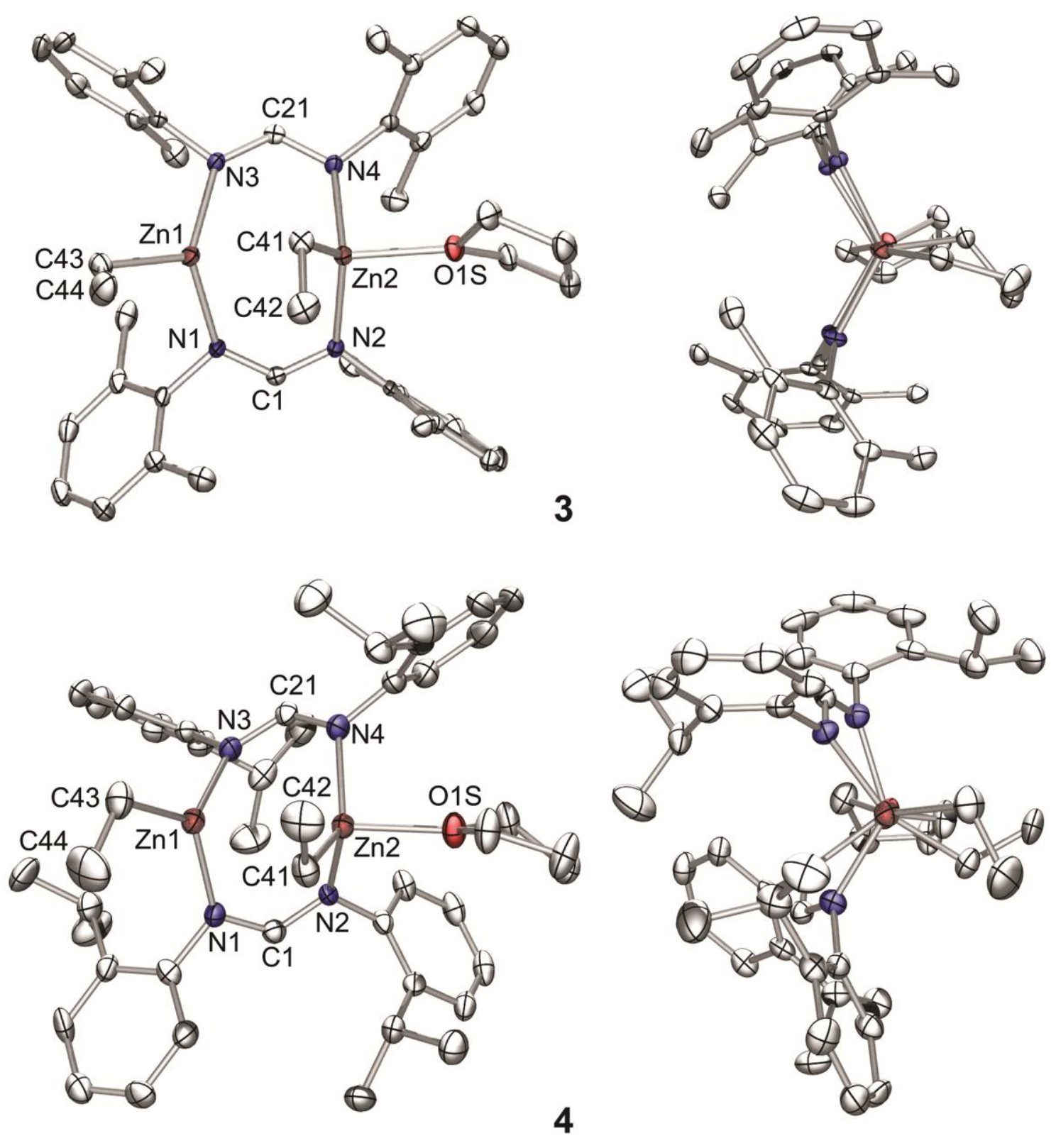

Figure 4. X-ray crystal structures of $\mathbf{3}$ (top) and $\mathbf{4}$ (bottom). Left: Front view. Right: Side view. Hydrogen atoms are omitted for clarity. Ellipsoids are shown at the 50\% probability level. 


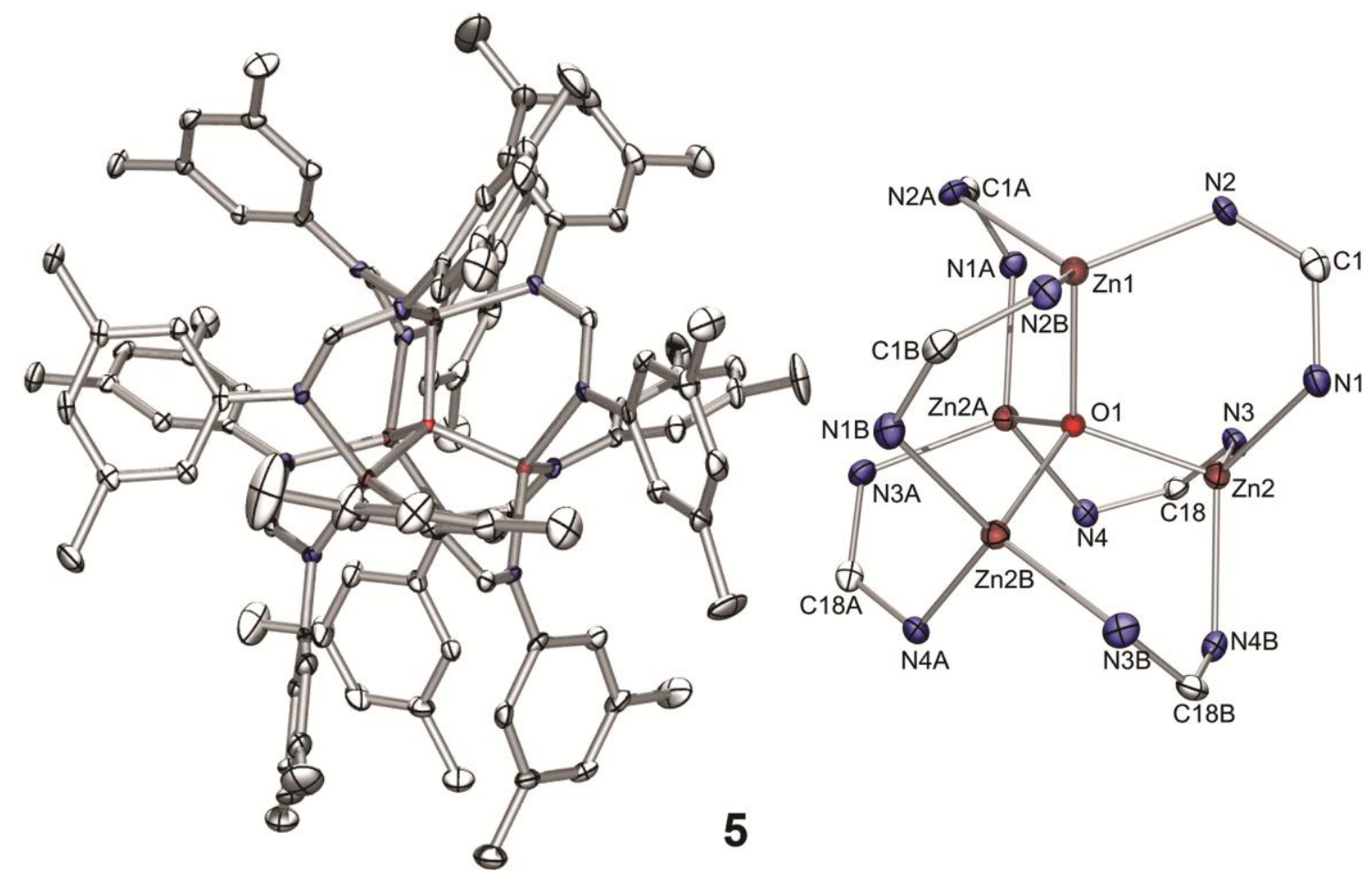

Figure 5. Left: X-ray crystal structure of cluster 5. Hydrogen atoms are omitted for clarity. Right: An illustration of the central core in $\mathbf{5}$ showing the tetrahedral arrangement of the $\mathrm{Zn}$ atoms around the central oxygen and the distribution of DArF ligands. Aryl groups and hydrogen atoms are omitted for clarity. Ellipsoids are shown at the 50\% probability level.

\section{References}

${ }^{1}$ C. J. Gerhardt, Liebigs Ann. Chem. 108 (1858) 219.

2 (a) F. T. Edelmann, Coord. Chem. Rev. 137 (1994) 403. (b) J. A. R. Schmidt, J. Arnold, J. Chem. Soc., Dalton Trans. (2002) 3454. (c) S. Enthaler, K. Schröder, S. Inoue, B.

Eckhardt, K. Junge, M. Beller, M. Dreß, Eur. J. Org. Chem. (2010) 4893. (d) R. T. Boeré, M. L. Cole, P. C. Junk, New J. Chem. 29 (2005) 128. (e) A. D. Bond, D. J. Linton, P. Schooler, A. E.H. Wheatley, J. Chem. Soc., Dalton Trans. (2001) 3173. (f) J.-K. Buijink, M. Noltemeyer, F. T. Edelmann, Z. Naturforsch. 46b (1991) 1328. (g) M. P. Coles, Dalton Trans. (2006) 985. (h) J. Barker, M. Kilner, Coord. Chem. Rev. 133 (1994) 219. 
${ }^{3}$ F. A. Cotton, C. A. Murillo, R. A. Walton, (Eds.), Multiple Bonds Between Metal Atoms, $3^{\text {rd }}$ ed., Springer Science and Business and Media, Inc., New York, 2005.

${ }^{4}$ (a) W. Marckwald, Liebigs Ann. Chem. 286 (1895) 343. (b) E. C. Taylor, W. A. Ehrhart, J. Org. Chem. 28 (1963) 1108.

5 (a) T. Ren, S. Radak, Y. Ni, G. Xu, C. Lin, K. L. Shaffer, V. DeSilva, J. Chem. Cryst. 32 (2002) 197. (b) R. Anulewicz, I. Wawer, T. M. Krygowski, F. Männle, H.-H. Limbach, J. Am. Chem. Soc. 119 (1997) 12223. (c) S. J. Archibald, N. W. Alcock, D. H. Busch, D. R. Whitcomb, Inorg. Chem. 38 (1999) 5571. (d) T. Ren, C. Lin, P. Amalberti, D. Macikena, J. D. Protasiewicz, J. C. Baum, T. L. Gibson, Inorg. Chem. Comm. 1 (1998) 23. (e) C.-W. Yeh, H.-L. Hu, R.-H. Liang, K.-M. Wang, T.-Y. Yen, J.-D. Chen, J.-C. Wang, Polyhedron 24 (2005) 539.

${ }^{6}$ (a) T. Ren, Coord. Chem. Rev. 175 (1998) 43. (b) K. M. Kadish, T. D. Phan, L. Giribabu, E. V. Caemelbecke, J. L. Bear, Inorg. Chem. 42 (2003) 8663.

${ }^{7}$ F. A. Cotton, L. M. Daniels, D. J. Maloney, J. H. Matonic, C. A. Murillo, Polyhedron 13 (1994) 815.

${ }^{8}$ M. L. Cole, G. B. Deacon, C. M. Forsyth, K. Kristina, P. C. Junk, Dalton Trans. (2006) 3360.

9 D. A. Kissounko, M. V. Zabalov, G. P. Brusova, D. A. Lemenovskii, Russ. Chem. Rev. 75 (2006) 351.

${ }^{10}$ M. L. Cole, A. J. Davies, C. Jones, P. C. Junk, New. J. Chem. 29 (2005) 1404.

${ }^{11}$ (a) T.-G. Ong, G. P. A. Yap, D. S. Richeson, Chem. Commun. (2003) 2612. (b) P. B. Hitchcock, M. F. Lappert, M. Layh, J. Chem. Soc., Dalton Trans. (1998) 3113.

${ }^{12}$ (a) F. A. Cotton, S. C. Haefner, J. H. Matonic, X. P. Wang, C.A. Murillo, Polyhedron 16 (1997) 541. (b) S. Bambirra, M. J. R. Brandsma, E. A. C. Brussee, A. Meetsma, B. Hessen, J. H. Teuben, Organometallics 19 (2000) 3197. (c) M. L. Cole, P. C. Junk, L. M. Louis, J. Chem. Soc., Dalton Trans. (2002) 3906. (d) M. L. Cole, D. J. Evans, P. C. Junk, M. K. Smith, Chem. Eur. J. 9 (2003) 415.

${ }^{13}$ Y.-C. Liu, W.-Y. Yeh, G.-H. Lee, S.-M. Peng, Organometallics 22 (2003) 4163.

${ }^{14}$ (a) G. B. Deacon, P. C. Junk, L. K. Macreadie, D. Werner, Eur. J. Inorg. Chem. (2014) 5240. (b) D. Werner, G. B. Deacon, P. C. Junk, R. Anwander, Chem. Eur. J. 20 (2014) 4426. (c) M. L. Cole, G. B. Deacon, C. M. Forsyth, P. C. Junk, K. Konstas, J. Wang, Chem. Eur. J. 13 (2007) 8092.

${ }^{15}$ L. A. Lesikar, A. F. Richards, Polyhedron 29 (2010) 1411.

${ }^{16}$ C. Jones, L. Furness, S. Nembenna, R. P. Rose, S. Aldridge, A. Stasch, Dalton Trans. 39 (2010) 8788.

${ }^{17}$ (a) F.A. Cotton, L.M. Daniels, L.R. Falvello, J.H. Matonic, C.A. Murillo, X. Wang, H. Zhou, Inorg. Chim. Acta 266 (1997) 91. (b) M. L. Coles, D. J. Evans, P. C. Junk, L. M. Louis, New J. Chem. 26 (2002) 1015.

${ }^{18}$ N. Nimitsiriwat, V. C. Gibson, E. L. Marshall, P. Takolpuckdee, A. K. Tomov, A. J. P. White, D. J. Williams, M. R. J. Elsegood, S. H. Dale, Inorg. Chem. 46 (2007) 9988.

${ }^{19}$ F. A. Cotton, L. M. Daniels, C. A. Murillo, P. Schooler, J. Chem. Soc., Dalton Trans. (2000) 2001.

${ }^{20}$ (a) I. Resa, E. Carmona, E. Gutierrez-Puebla, A. Monge, Science 305 (2004) 1136. (b)

D. del Río, A. Galindo, I. Resa, E. Carmona, Angew. Chem., Int. Ed. 44 (2005) 1244.

(c) Y. Wang, B. Quillian, P. Wei, H. Wang, X.-J. Yang, Y. Xie, R. B. King, P. v.R. 
Rchleyer, H. F. III Schaefer, G. H. Robinson, J. Am. Chem. Soc. 127 (2005) 11944. (e) S. Schulz, D. Schuchmann, U. Westphal, M. Bolte, Organometallics 28 (2009) 1590. (f) A. Stasch, Chem. Eur. J. 18 (2012) 15105. (g) Z. Zhu, R. J. Wright, M.M. Olmstead, E. Rivard, M. Brynda, P. P. Power, Angew Chem. Int. Ed. 45 (2006) 5807.

${ }^{21}$ (a) I. Resa, E. Carmona, E. Cutierrez-Puebla, A. Monge, Science 305 (2004) 1136. (b) D. del Río, A. Galindo, I. Resa, E. Carmona, Angew. Chem., Int. Ed. 44 (2005), 1244.

${ }^{22}$ H. Koyama, Y. Saito, Bull. Chem. Soc. Japan 27 (1954) 112.

${ }^{23}$ H. Chun, H. Jung, Inorg. Chem. 48 (2009) 417.

${ }^{24}$ W. H. Bragg, Nature 111 (1923) 532.

25 (a) A. R. Corcos, A. K. M. Long, I. A. Guzei, J. F. Berry, Eur. J. Inorg. Chem. (2013) 3808. (b) S. Kuppuswamy, T. M. Powers, B. M. Johnson, C. K. Brozek, J. P. Krogman, M. W. Bezpalko, L. A. Berben, J. M. Keith, B. M. Foxman, C. M. Thomas, Inorg. Chem. 53 (2014) 5429. (c) S. J. Tereniak, R. K Carlson, L. J. Clouston, V. G., Jr. Young, E. Bill, R. Maurice, Y.-S. Cheng, H. J. Kim, L. Gagliardi, C. C. Lu, J. Am. Chem. Soc. 136 (2014) 1842.

${ }^{26}$ M. L. Hlavinka, J. R. Hagadorn, Organometallics 25 (2006) 3501.

${ }^{27}$ APEX2 v.2009 Bruker Analytical X-Ray Systems, Inc: Madison, WI, 2009.

${ }^{28}$ G. M. Sheldrick, SADABS, Version 2.03 Bruker Analytical X-Ray Systems, Inc: Madison, WI, 2000.

${ }^{29}$ A. L. Spek, PLATON, A Multipurpose Crystallographic Tool Utrecht University, Utrecht, The Netherlands, 2010.

${ }^{30}$ G. M. Sheldrick, SHELXTL, Version 6.14 Bruker Analytical X-Ray Systems, Inc: Madison, WI, 2008.

${ }^{31}$ L. J. Farrugia, J. Appl. Cryst. 45 (2012) 849.

${ }^{32}$ Persistence of Vision Pty. Ltd. Persistence of Vision (TM) Raytracer: Williamstown, Victoria, Australia, 2004. http://www. povray.org/. 


\section{Graphic Abstract:}

It was found that the steric properties of $N, N$-diarylformamidinates controlled the geometry and nuclearity of the $\mathrm{Zn}$ products. Increase in steric demands of the ligands decreased the complex nuclearity from three to two. Ligands in the trinuclear clusters resided in non-symmetric coordination modes in both solid state and solution phase.

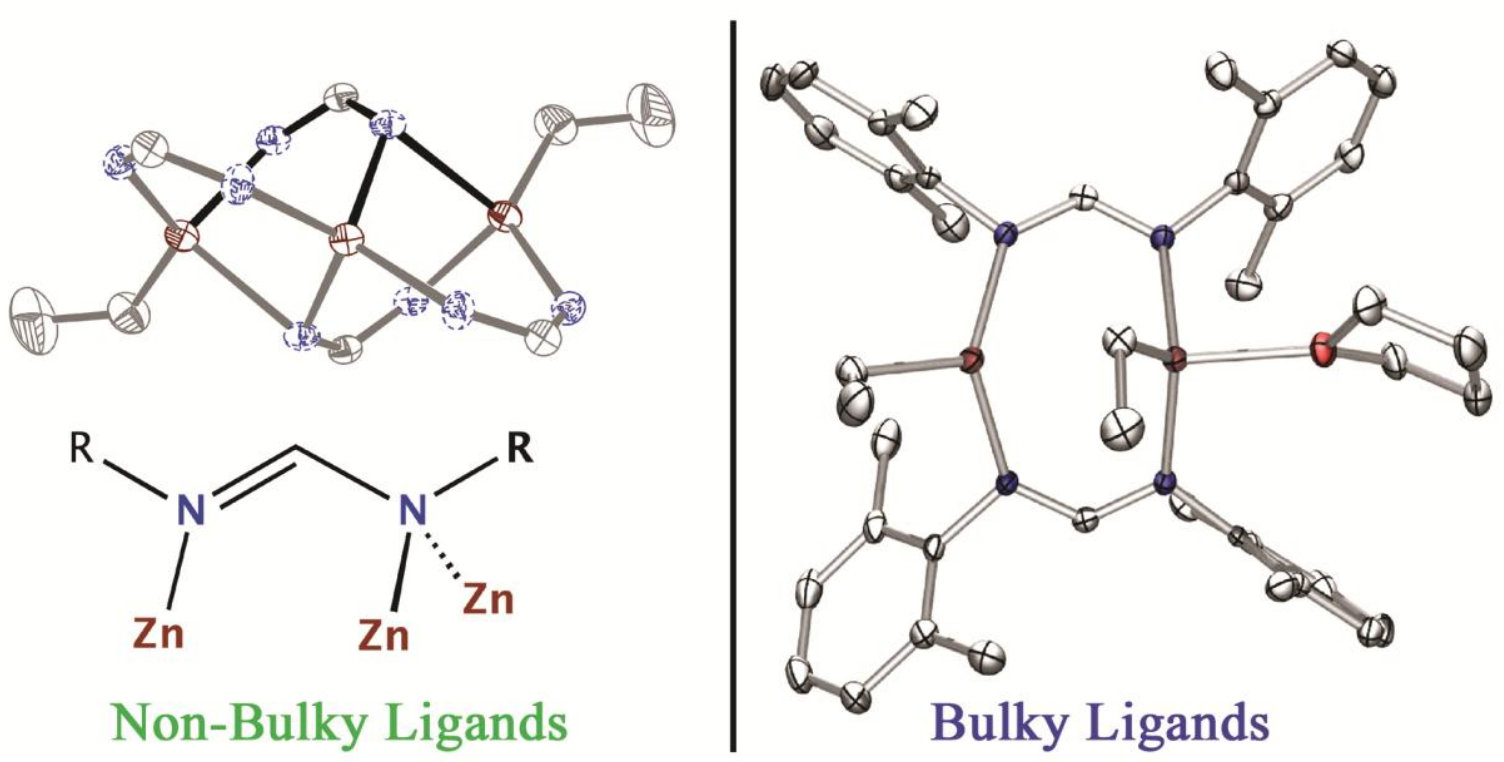

